\title{
TUTKIVAT OPPIJAT
}

\author{
Hakkarainen, Kai, \\ Lonka, Kirsti \& Lippo- \\ nen, Lasse (1999) Tutki- \\ va oppiminen, älyk- \\ kään toiminnan rajat \\ ja niiden ylittäminen. \\ Porvoo: WSOY. 295 s.
}

Käsissä on inspiroiva ja haastava kirja. Kirjan esittelyn voisi tietysti saman tien päättää tähän ja suositella sen lukemista. Lienee kuitenkin syytä perustella avaus. Kirjassa esitetään tutkivan oppimisen malli sekä välineitä ja toimintatapoja mallin soveltamiseen käytännössä. Kirja on kohdistettu oppimisen, älykkyyden ja ajattelun kehittämisestä kiinnostuneille. Meitä on suuri määrä lastentarhoista ylempiin opinahjoihin ja työelämään. Esittelen aluksi kirjan sisällön hyvin yleisellä tasolla. Sitten esittelen kirjan sisältöä lukiessa syntyneiden assosiaatioiden ohjaamana. Lopuksi esitän yleisarvion.

\section{Kirjan sisältö}

Johdannon jälkeen, jossa esitetään kirjan tiedeperusta, siirrytään pohtimaan ihmisen tiedonkäsittelyn rajoituksia. Sitten nostetaan esille kysymys siitä, miten asiantuntijuus kehittyy ja miksi käsitteellinen muutos on vaikeaa. Viidennessä luvussa esitellään ajattelun työvälineitä älykkään toiminnan rajojen ylittämiseen. Muiden ihmisten ja metakognitiivisten taitojen merkitys oppimiselle on kahden seuraavan luvun aiheena. Tutkivan oppimisen malli esitetään luvussa kahdeksan. Yhdeksännen luvun aiheena on ongelmien asettamisen merkitys tutkivassa oppimisessa eli ongelmalähtöinen opetus tutkivan oppimisen käytännöllisenä muotona. Tutkivan oppimisen ja oppijan omien selitysten merkitystä käsitellään seuraavassa luvussa. Yhdennentoista luvun otsikkona on: "Kohti kriittistä ajattelua". Lopuksi asiat vedetään yhteen. Kirjan lopusta löytyy myös keskeisin sanasto. Lukijan navigointia tekstissä tukee kirjassa seikkaileva perhe, jonka isänä on Pekka "Pölvästi", hänen älykkövaimonsa Jaana sekä tyhmiä kysymyksiä esittelevä Mikko-poika ja ajattelun aakkosia opetteleva Liisavauva.

\section{Muutoksessa tarvitaan} monenlaista oppimista. Oppimiskykyä tarvitaan siksi, että muutos on ikuista. Lisäksi tiedon määrä ja monimutkaisuus eli työn tietointensiivisyys kasvaa. Olennaisen löytäminen informaation markkinoilta ja roskakasoista edellyttää uudenlaista, aiempaa korkeamman tasoista ja strategista osaamista. Työstä on tullut kaiken kaikkiaan välittyneempää eli käsiteohjautuvaa. Tiedon ja osaamisen luonne muuttuu sikäli, että kirjanoppineisuus ei riitä, sillä pysyvää, "oikeaa" tietoa on vain vähän. Yksilöllisen oppimisen harha törmää omien ratkaisujen riittämättömyyteen; oppiminen sosiaalistuu. Tarvitsemme muita. Tutkivan oppimisen kautta ajattelukykymme ja -tapamme tieteellistyy. Oppivan organisaation malleissa on vastaavalla tavalla pohdittu erilaisten toimintaympäristö- jen oppimishaasteita. Vaatimattomimmillaan oppiminen on sopeutumista ja vaativimmillaan rajoja ylittävää luovaa toimintaa turbulentissa ympäristössä.

\section{Tiedonkäsittelyn rajat} Kirjassa esitetään useita ihmisen yksilöllisen tiedonkäsittelyn rajoituksia, kuten valikoiva tarkkaavaisuus, työmuistin kapasiteetti, pitkäkestoisen muistissa olevan tiedon löytämiseen ja uudelleen muodostamiseen liittyvät vaikeudet sekä kyvyttömyys ymmärtää oman muistamisen rajoituksia. Kirjoittajat kysyvät oikeutetusti, kuinka järkiperäisesti ihminen loppujen lopuksi ajattelee - jos ajattelee lainkaan. Keskeinen kuvitelma on, että ihminen ajattelee empiristisesti, tieteellisesti tähdäten todellisuuden kuvaamiseen ja selittämiseen hypoteesien testaamisen välityksellä. Kirjassa kuvataan hauskasti ihmisten tosiasiallinen ajattelu, joka perustuu vinoutumiin, uskomuksiin ja stereotypioihin. Asioita ei muisteta, vaan ne konstruoidaan. Pyrimme etsimään vahvistusta omille oletuksillemme (vahvistusilluusio). Mielenkiintoisinta on se, että edes tieteessä ei ajatella "tieteellisesti", vaan sama vahvistusilluusio vallitsee. Mieleen tulee positivismin ja laadullisen tutkimusotteen edustajien jatkuva toistensa ohipuhuminen. Vai olisiko sittenkin kysymys vallasta ja politiikasta? Kirjan sanoma on, että olennaista on tietää päättelykykymme rajat. Vaikka idealisoitu käsitys ajattelusta tieteellisenä päättelynä ei pi- 
däkään paikkaansa, on hyödyllistä tietää sen rajat.

Älykkyys ja asiantuntijuus Kolmas luku käsittelee älykkyyttä. Keskeinen kritiikin kohde on testeillä mitattu älykkyys. Roomaan ei kuitenkaan ole yhtä tietä. Tekijät puhuvat dynaamisesta, systeemisestä älykkyydestä, joka syntyy vuorovaikutuksessa toimintaympäristön kanssa. Älykästä eri ympäristöissä ovat eri tekijät, näin ollen testiälykkyys ei toimi. Älykkyys ilmenee musiikillisessa, kehollisessa, emotionaalisessa ja sosiaalisessa muodossa. Erilaiset ympäristöt tukevat älykästä toimintaa, esimerkiksi tietotukijärjestelmät. Älykkyys on kontekstisidonnaista ja usein käytännöllistä, älykästä toimintaa.

\section{Syntyy kysymys siitä,} voiko älykkyyttä kehittää? Jos asiantuntijoita pidetään omalla alallaan älykkäästi toimivina, niin kirjan vastaus on kyllä. Mitä keinoja sitten on: esimerkiksi työmuistin kokoa voidaan suurentaa harjoittelulla, muodostuu suurempia hallittavia kokonaisuuksia ja muististrategioita, osa toiminnan säätelystä automatisoituu. Mielenkiintoinen uusi käsite on pitkäkestoinen työmuisti eli pitkäkestoisen muistin käyttö omalla asiantuntemuksen alueella varsinaisen työmuistin tapaan. Asiantuntijuuden ytimenä on uusien ongelmien ratkaisutaitojen kehittyminen. Motiivina kenties huippuelämyksen haku. Tarkoituksellinen harjoittelu on huipputaidon päätekijä, sanovat kirjoittajat. Huippuosaajat siis yksinkertaisesti tekevät omaa asiaansa enemmän ja intensiivisemmin. Viisi prosenttia inspiraatiota ja 95 perspiraatiota siis sopivat hyvin nerokkaan toiminnan lähteiksi. Pelkkä tekeminen ei kuitenkaan riitä, vaan tarvitaan pohdiskelua ja reflektiivistä ajattelua. Herää kysymys, mikä on toimintaympäristön rooli? Älykäs toiminta ei ole yksilölähtöistä, vaan tarvitaan asiantuntijakulttuuri.

\section{Miksi pää kuitenkin}

pysyy tyhjänä? Kouluopetusta pohtiessaan tekijät pyrkivät vastaavaan "tyhjän pään" ongelmaan. Esitetään muutama hyvä käsite, kuten "eloton tieto", jolla tarkoitetaan kouluopetuksen myötä syntyneitä irrallisia tietoja, joita ei osata soveltaa. Peruslähtökohtana on ajatus, että oppimisen myötä syntyneet ajattelumallit ohjaavat huomion kiinnittymistä. Usein opitaan vain pinnallisesti, eikä näin opittua tietoa osata soveltaa. Tästä aiheutuu käsitteellisen muutoksen ongelma. Opetus ei useinkaan vaikuta. Arkikokemuksen myötä syntynyt oma teoria vangitsee. Muutos tapahtuu käsitteellisen rikastumisen ja muutoksen kautta. Rikastuminen viittaa vähittäiseen muutokseen. Muutos tarkoittaa radikaalimpaa hyppäystä ja uusien ydinkäsitteiden muodostumista. Ajattelu kehittyy tällöin umpikujien kautta. Myös motiivit ja tavoitteet vaikuttavat. Ajattelun muuttumattomuus kuvastaa myös ympäristön staattisuutta. Tyhjä pää pysyy tyhjänä, koska opiskelu tapahtuu irrallaan uuden tiedon luomisesta, mikä tapahtuu asiantuntijayhteisöissä. Opittua tietoa ei voida erottaa siitä ympäristöstä, jossa se on opittu. Tämä päätelmä tukee tiedekorkeakoulun asemaa tutkimuksen ja opetuksen yhdistäjänä. Ongelmana tosin on käytännössä se, että tutkijat eivät usein halua opettaa ja opettajat eivät ehdi tutkia.

Ihminen käyttää monella tapaa hyväkseen ympäristönsä tietoa, mikä mahdollistaa älykkään toiminnan rajojen ylittämisen. Ympäristö helpottaa toimimista. Kirjan ajatusta tukevat myös omat työympäristöissä tehdyt tutkimuksemme, jossa toiminnan helpottamista haettiin oman muistin lisäksi fyysisestä työympäristöstä, muista ihmisistä ja tietotukijärjestelmistä. Tuttu ympäristö aktivoi muistia. Muisti on hajautuneena ympäristöön ja ihmiseen. Normaniin ja Hutchinsiin nojautuen kirjoittajat korostavat fysikaalisesti ja sosiaalisesti hajautettua kognitiota. Ensin mainittu viittaa yksilön toimimiseen ajattelun työvälineiden (välineet ja käytännöt) avulla ja toinen taas muiden ihmisten kanssa. Työvälineajattelu tuo kuvaan mukaan Vygotskin, jota Suomessa erityisesti kehittävä työntutkimus on hyödyntänyt teoreettisissa muotoiluissaan ja käytännön toimenpiteissään.

\section{Ajattelun työvälineiden} erittely osoittaa kirjoituksen tärkeäksi tyhjän pään täyttämisen välineeksi. Kuvallinen esittäminen on sitä myös. Kirjoittaminen on kuitenkin kaikkein tärkein ajattelemaan oppimisen väline. Kirjoittamistaidon kehittämiseen voidaan käyttää toiminnallista tukea eli ohjeita kirjoittamisen aikana ja prosessikirjoittamista. Tekstien opiskelustrategiat ovat usein toistavia, kuten mekaaninen kertaus. Tietoa muokkaavia strategioita ovat 
mm. tiivistelmien kirjoittaminen ja käsitekartat. Niiden avulla syntyy kehittynyt sisältömalli tekstistä. Muistiinpanot toimivat apuvälineinä. Tekijät pitävät tietokoneavusteisia oppimisympäristöjä eräänä lupaavimmista ajattelua tukevista työvälineistä. Tähän voisi lisätä myös muita ulkoistamisen välineitä, jotka mahdollistavat reflektiivisen ajattelun. Tällaisia ovat esimerkiksi monimutkaisten ilmiöiden mallintamiseen käytetyt simulaatiopelit. Keskeinen tutkimuskysymys niiden toimivuuden ja hyödyn osalta on siirtovaikutuksen osoittaminen todelliseen toimintaan. Käsitteet, argumentit ja ajattelutapa saattavat kyllä muuttua, mutta muuttuuko käytäntö? Tähän on helppo vastata, että ajattelu on toimintaa, jonka kohteena ovat käsitteet. Tämä ei kuitenkaan helpota, kun ajatteluun liitetään toiminta aineellisten kohteiden kanssa.

\section{Sosiaalisen tietotuen}

merkitys tulee hyvin esille käsiteltäessä jaettua asiantuntijuutta älykkään toiminnan kehittymisen tukena luvussa kuusi. Tiimi on kognitiivinen järjestelmä. Tietämyksen hallinta eli Knowledge Management saa hieman kapean merkityksen organisaation sellaisena toimintana ja johtamiseen liittyvinä käytäntöinä, joiden avulla voidaan tukea organisaation jäsenten asiantuntijuuden kehittymistä ja jakamista. Uuden tiedon muodostaminen, formalisointi, ylläpito ja jakaminen ovat keskeisiä tekijöitä. Monet oppivan organisaation gurut korostivat 90-luvulla tässä yhteydessä dialogin eli vuoropuhelun merkitystä. Mikä ta- hansa keskustelun tapa ja yhteys ei kuitenkaan vie haluttuun lopputulokseen. Oppiminen tulee kytkeä asiantuntijayhteisöjen toimintaan.

Käytännöllisinä keinoina ovat kognitiivisen kisällioppimisen mallit, joissa oppilasta ohjataan järjestelmällisesti harjoittamaan asiantuntijalle tyypillisiä henkisiä prosesseja ja toimintakäytäntöjä. Mallittaminen, ohjaus (tutor), valmentaminen (coach) ja rakennustelineiden luominen (scaffold) ovat avainsanoja.

\section{Ja sitten on vielä itse- kriittisyys}

Seitsemännen luvun aiheena on metakognitiivisten ja itsearvioinnin taitojen kehittyminen. Metakognitio tarkoittaa kykyä asettua oman osaamisensa arvioijaksi. Tiedon eri lajeihin (data, informaatio, tieto, viisaus) kuuluva "viisaus" saa sternbergiläisen tulkinnan: viisaus on sitä, että ihminen tuntee omat tietonsa, tietää, mitä ei tiedä ja oivaltaa, mitä hän periaatteessa voisi tietää. Metakognitio kehittyy kirjoittajien mukaan Vygotskin mallin mukaan siten, että itsensä ohjaus siirtyy ulkoa sisälle toiminnallisen tuen ansiosta. Kielen merkitys metakognitiossa on keskeinen. Tässä onkin dialogien käymisen keskeinen merkitys. Sen avulla päästään käsiksi toisen ihmisen ja omiin tiedollisin ja metakognitiivisiin prosesseihin. Oppimisympäristö kuvataan yksilön ympäristön toiminnallisina ominaisuuksina ja rakenteina sekä niinä työvälineinä ja työkaluina, joita voidaan käyttää oppimisen tukena. Opetus ja oppiminen siis liitetään kiinteästi toisiinsa. Entä oppiminen ja käytännöllinen toiminta?
Tutkivan oppimisen malli alustetaan esittelemällä muita opetus- ja oppimisprosessin malleja. Mallia tarjotaan keinoksi oppia korkeatasoista oppimista. Keskeistä on oppijan itsesäätelyn ja toisaalta ulkoisen säätelyn suhde. Oppimista voidaan tukea ja aktivoida erilaisilla ajattelun apuvälineillä, kuten kirjoittamisella, oppimispäiväkirjoilla, luonnosten tekemisellä ja kehittämiskansioilla. Aktivoiva opetus perustuu opettajan näkökulmasta kolmivaiheiseen sykliin, joka käynnistyy aiempien ajattelumallien diagnosoinnilla ja aktivoinnilla sekä jatkuu oppimisprosessin ja reflektiivisen ajattelun tukemisella ja palautteen antamisella ja väärinymmärrysten haastamisella.

Malli pohjautuu olemassa olevien oppimiskäsitysten kritiikkiin. Perinteinen käsitys näkee mielen säiliönä. Opettajan säiliöstä siirretään tietoa oppilaan säiliöön. Konstruktivistinen oppimiskäsitys, joka korostaa opiskelijan aktiivisuutta, perustuu kirjoittajien mukaan myös säiliömalliin. Aktiivisuus tiedonkäsittelyssä ei selitä niitä mekanismeja, joiden välityksellä uusi tieto syntyy tai tieto kehittyy. Asiantuntijan tietorakenteet eivät tule mielen syvyydestä, vaan edustavat kulttuurin tietorakenteita. Oppiminen on siis tiedon rakentelua, uuden luomista.

Scardamalian ja Bereiterin nojautuen esitetään kolme oppimisen tasoa: (1) tahaton oppiminen, (2) tietoinen oppiminen ja (3) tiedon rakenteleminen. Oppimisympäristöt tarjoavat opiskelijoille yhteisöllisen tiedonrakentelun vä- 
lineitä. Tutkivassa oppimisessa oppimisprosessia tarkastellaan oppimisen ja tiedonrakentelun välisenä vuorovaikutussuhteena. Uuden tiedon luominen on olennaisesti samanlainen prosessi kuin aikaisemmin luodun tiedon ymmärtäminen. Oppimisyhteisö on organisoitava tiedeyhteisön tapaan. Olennaista on tiedon käsittely toiminnan kohteena.

\section{Tutkivan oppimisen}

prosessissa on seuraavat osatekijät: (a) Kontekstin luominen ja opetuksen ankkuroiminen opiskelijan aikaisempiin kokemuksiin, (b) ongelmien asettaminen, (c) omien työskentelyteorioiden luominen, (d) kriittinen arviointi, jossa opiskelija arvioi kriittisesti tutkimusprosessinsa etenemistä, (e) uuden, syventävän tiedon hankkiminen, (f) asiantuntijuuden jakaminen. Tämän pohjalta voi syntyä uusi työskentelyteoria.

\section{Ongelmalähtöinen}

oppiminen, jota esitellään luvussa yhdeksän, on tutkivan oppimisen käytännön sovellus. Tekijät torjuvat tekemällä oppimisen melko jyrkästi kirjoittamalla: "Tutkiva oppiminen ei ole tekemällä oppimista". Tutkivassa oppimisessa ratkaisua ongelmaan haetaan aikaisemmin hankitun tiedon sijasta hakemalla vastaus etsimällä järjestelmällisesti merkityksellistä uutta tietoa erilaisista tiedonlähteistä. Kirjan lähestymistavan eräs rajoitus tulee esille tässä yhteydessä: oppimista synnyttävät ongelmat nähdään pääosin tiedollisina ongelmina. Tämä pitääkin paikkansa oppilaitosympäristössä, joita syystä usein pidetään käytännöistä vieraantuneina paikkoina. Kuitenkin työelämän ympäristössä ongelmat usein ovat läsnä koko ajan sulautuneena käytännön toimintaan. Tähän toki liittyy myös tiedollinen osatekijä. Oppiminen siis olisi paitsi tiedon hakemista ja hypoteesien muotoilemista myös niiden kokeilua.

\section{Kirjan loppuosassa}

syvennetään tutkivan oppimisen taustakäsitteitä. Keskeisenä kohteena on selittämisen ja päättelyn tarkastelu. Teksti saa pohdiskelevan filosofisen luonteen. Aluksi käsitellään itselleen selittämisen merkitystä oppimisen kannalta, esimerkiksi itselleen puhumista. Työskentelyteorioiden merkitys on yhtenä aiheena. Hyvin tunnetuista päättelymuodoista valitaan abduktio, eli uusien käsitteiden ja selittävien teorioiden luomisen prosessi, induktiota ja deduktiota paremmin kuvaamaan tutkivan oppimisen päättelyä. Parhaan selityksen löytäminen edellyttää usein sosiaalista vuorovaikutusta ja älyllisen toiminnan työnjakoa. Kysymys on siis keskinäisestä oppimisesta: tietojen välittämisestä ja täsmennysten vaatimisesta.

\section{Lopuksi pohditaan} kriittistä ajattelua ja metakognitiivisten taitojen merkitystä siinä. Kriittisessä ajattelussa päätelmän (väitteen, uskomuksen, teorian) ja evidenssin erottaminen toisistaan on keskeistä. Korkealaatuisen oppimisen tuloksena on tällainen kriittisen ajattelun taito. Tekstien tulkinnassa tämä tarkoittaa retorista näkökulmaa, jossa pohditaan argumenttien motiiveja. Metakäsitteellinen tietoisuus on tutkivan oppimisen tavoitteena. Tämä tapahtuu, kun oppija alkaa tar- kastelemaan omia käsityksiään hypoteeseina. Metakäsitteellinen tietoisuus muodostuu empiirisestä tasosta, teoreettisesta tasosta ja metakäsitteellisestä tasosta, jolla yksilö oppii käsitteellistämään tieteellisessä tutkimuksessa tarvittavia menetelmiä ja prosesseja sekä niitä tukevia todistusaineistoja. Oppimisympäristö voi toimia metakognitiivisena ympäristönä, jonka avulla käytön avulla metakäsitteellinen tieto voi siirtyä oppilaan omaksi tiedoksi.

\section{Päätelmiä kirjasta}

Mietin, mikä voisi olla kriittinen näkökulma kriittiseen kirjaan menemättä johonkin merkityksettömään yksityiskohtaan? Kirjan puoleen välin mennessä en ollut vielä keksinyt mitään. Useimmat oppimiseen liittyvistä asioista ja käsitteistä lienevät yleispäteviä toimintaympäristöstä riippumatta. Sitten havaitsin kirjan rajoittumisen institutionaaliseen oppilaitosympäristöön. Soveltuuko tutkiva oppiminen työelämän tarpeisiin? Koulua tai yliopistoa muistuttavia tilanteita kun on vähän. Tutkivassa oppimisessa oppiminen tapahtuu ehkä hieman irrallaan käytännön toiminnasta, omassa rationaalisessa reflektoinnin kehässään. Oppimissyklin keskeinen puute on toiminnan käsitteen puuttuminen, mikä saa sen muistuttamaan rationalistista, mielen sisäistä päättelyketjua, olkoonkin se jaettua, ajattelua ja opettajan kulttuuria välittävää tukea. Onko filosofisena valintana kuitenkin rationalismi empirismin tai niiden yhdistämisen sijaan? 
Näkökulma, jota olemme pohtineet omassa tutkimus- ja kehittämistoiminnassamme on oppimisen kiinteämpi yhdistäminen välittömään työtoimintaan. Työelämässä opettelun eriyttäminen omaksi toiminnakseen ei tuota hyviä oppimistuloksia. Ideaalista olisi oppimisen, toiminnan ja sen käsitteellistämisen yhdistäminen toisiinsa. Tämä jo siksi, että työelämän haasteet turbulenteissa ympäristöissä eivät anna mahdollisuuksia erillisiin oppimistilanteisiin. Tämän vuoksi työnopetus ja työtoiminnan aikainen tietotuki erotetaan toisistaan, vaikka molemmat synnyttävät uusia tiedollisia rakenteita. Epäselväksi jää, syntyykö kehittyneestä ja korkeatasoisesta ajattelusta myös korkeatasoista toimintaa?

Toinen seikka, jota jäin kirjassa hieman kaipaamaan, on tutkivan oppimisen syklimallin suhteuttaminen muihin vastaavin malleihin, kuten Deweyn, Kolbin, Batesonin, Argyriksen ja Schönin sekä Engeströmin malleihin. Myös Galperin olisi kaivannut kriittistä kommentointia. Esittihän Galperin varsin yksityiskohtaisen mallin ja vaihekuvauksen henkisten toimintojen ja toiminnan itsesäätelyn sisäistymisestä.

\section{Kirja ei ole helppo, vaan} edellyttää vähintään konstruktivistista otetta kokonaiskuvan luomiseksi. Se on filosofinen pohtiessaan tiedon luonnetta ja syntyä. Kaiken kaikkiaan kysymyksessä on erinomainen katsaus ihmisen tiedonkäsittelyyn ja ajatteluun. Kirja kokoaa hyvin yhteen oppimisen, ajattelun sekä niiden kognitiivisen ja filosofisen perustelun keskeiset käsitteet. Hauskoja ovat kokeiden esit- telyt, joilla konkretisoidaan muuten käsitteellisesti täyttä tekstiä. Ajatus oppilaista potentiaalisina asiantuntijoina edustaa melkoista kehitysoptimismia elitismin sijaan. Kiinnostavaa ja tärkeää kirjassa on sen ajatus oppimisesta asiantuntijuuden kehittymisenä, jossa keskeistä on oppijan vuorovaikutus sosiaalisen ja kulttuurisen toimintaympäristön kanssa. Kirjan perusvire on kriittinen. Se kyseenalaistaa lähestulkoon kaiken, esimerkiksi todellisuudesta irroitetun laboratoriotutkimuksen. Kirja soveltuu erinomaisesti oppimisen ja opetuksen oppikirjaksi. Erityisen hyödyllinen kirja on epäilemättä erilaista opetusta antaville ihmisille. Kiintoisa, koska käytännössä kaikki ovat istuneet oppilaana koulun penkillä.

Matti Vartiainen 